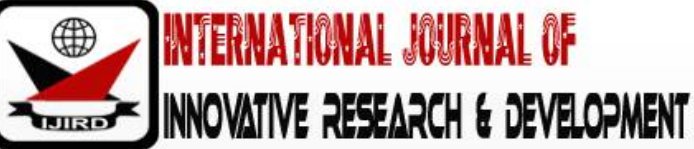

ISSN 2278 - 0211 (Online)

\section{Effect of Car, ROA, NIM, LDR and NPL on Stock Prices in Banking That Shared Listed In LQ45 Period 2013-2018}

Said Djamaluddin
Postgraduate Lecturer, Mercu Buana University, Jakarta, Indonesia
Indah Nadia Sari
Postgraduate Alumni, Mercu Buana University, Jakarta, Indonesia
Aty Herawaty
Postgraduate Lecturer, Mercu Buana University, Jakarta, Indonesia

\begin{abstract}
:
The aim of this study is to examine and analyze the effect of Capital Adequacy Ratio (CAR), Return on Assets (ROA), Net Interest Margin (NIM), Loan Deposit Ratio (LDR), and Non-Performing Loans (NPL) on banking stock prices listed in LQ45 2013-2018 period. Research data is secondary data for a 6-year observation period. The sampling method used is purposive sampling method, where all conventional commercial banks have only 6 banks registered in LQ45, namely BJB, BNI, Mandiri, BCA, BTN, and BRI which meet the criteria as samples. The analytical method used in this study is panel data regression. The results showed that CAR had a significant positive effect, but ROA, NIM, LDR, and NPL did not affect the banking stock price.
\end{abstract}

Keywords: Stock price, Capital Adequacy Ratio (CAR), Return on Assets (ROA), Net Interest Margin (NIM), Loan Deposit Ratio (LDR), and Non-Performing Loans (NPL)

\section{Introduction}

In running a banking business in its operational activities and credit business, banks have two types of funding sources, including funds originating from the bank itself and funds from the wider society such as current accounts, savings deposits, deposits and funds sourced from other institutions. The source of funds from the bank itself means the capital of deposits from shareholders who are interested in investing in banking shares. If the shares contained in the portfolio have not been sold out, while the need for funds is still needed, then the funding needs can be done by selling shares to the old shareholders. However, if the company aims to expand, the company can issue new shares and sell the new shares in the capital market.

In making an investment in the banking sector, investors usually tend to look at the LQ 45 list, namely the stock market index on the Indonesia Stock Exchange (IDX) which consists of 45 companies that meet certain criteria, which is included in the top 60 companies with the highest market capitalization 1 -2 months, included in the top 60 companies with the highest transaction value in the regular market in the last 12 months, have been listed on the Indonesia Stock Exchange for at least 3 months, have financial conditions, growth prospects and high transaction value. Based on data from the IDX in 2018 throughout August 27-31 2018, the JCI has dropped -49.71 points or equal to $0.83 \%$. The same goes for the LQ45 index, down -11.79 points, equivalent to $1.25 \%$. The decline in the prices of shares during the past week has been fairly even. From all the shares that became the LQ45 constituents, only 23 of them managed to rise from the previous week's closing price (24/8) including one of them was BJB, BNI, Bank BTN and Bank Mandiri. While BCA and BRI experienced a decline in the value of shares in the period of August 2018.

In this study the author will use fundamental analysis through financial ratios to assess stock prices in banks. In simple terms, stock prices can be predicted by analyzing available financial data. To analyze the financial condition of a company, investors can take advantage of their financial statements which are a description of the company's financial condition at a time or during a certain period.

CAR ratio on conventional commercial banks tend to increase in 2013-2017 followed by stock price movements on the Closing Price on LQ 45. However, in 2015 the value of the stock price somewhat decreased (792.03) when the CAR continues to increase from year $2014(19.31 \%)$. In the year 2018, the CAR ratio has decreased along (20.88\%) with a decrease in LQ45 Closing Price (982.73). The value of the ROA ratio tends to decline from 2013 to 2016 while the price of the LQ 45 Index Closing Price in the conventional general banking sector tends to increase from 2013 to 2017. However, the value of ROA increases (3.08\%) in 2018 when the LQ45 stock price falls to (982. 73). The conventional commercial bank's Net Interest Margin (NIM) ratio tends to increase and decrease from 2013 to 2017 when the value of the LQ45 
index Closing Price tends to increase in the same period. In 2018, the NIM ratio declined (5.7\%) from the previous year followed by a decrease in LQ45 Closing Prices. There is a decrease in the value of the LDR ratio in conventional commercial banks registered in LQ 45, but the value of Closing Prices tends to increase. In 2018 the LDR value increased to (92.83\%) when the value of Closing Price decreased to 982.73. The NPL value tends to decline from 2013 to 2016 but has increased again in 2017 to 2,049 \%. In 2018 the value of the NPL declined again (1.5\%) but followed the declining LQ45 closing price.

The relationship between financial ratios and stock prices is also evidenced by the research of Setyaningsih Sri Utami (2005) that CAR has a positive significant influence on the banking stock price on the IDX. While the LDR has a negative significant effect. Meanwhile according to Alvin Setiawan and Lauw Tjun Tjun (2010) that the LDR also has a significant positive effect on the banking stock price on the IDX. In addition, according to Gerald Edsel et al. Research (2017), ROA does not have a significant effect on banking stock prices. Then, in the research journal Yunaningsih Nino, Sri Murni, and Johan R. Tumiwa (2016) it was stated that the NPL partially had a significant positive influence on banking stock prices. Whereas according to Sigit Dwi Wismaryanto (2013) that NPL, CAR, ROA, LDR, and NIM have a significant influence on banking stock prices.

The purpose of this study is to obtain empirical evidence regarding the effect of Capital Adequacy Ratio (CAR), Return on Assets (ROA), Net Interest Margin (NIM), Loan to Deposit Ratio (LDR) and Non Performing Loans (NPL) to Closing Price on shares in the banking sector registered in the LQ 45 Index.

\section{Theoretical Review}

The stock price is the stock market closing price during the observation period for each type of stock sampled and its movements are always observed by investors. One of the basic concepts in financial management is that the goal of financial management is to maximize the value of the company. For companies that have gone public, this goal can be achieved by maximizing the market value of the stock price in question. Thus decision making is always based on consideration of the maximization of shareholders' wealth. according to Sartono (2008: 70) states that stock prices are formed through the mechanism of demand and supply in the capital market. If a share experiences an excess demand, then the stock price tends to rise. Conversely, if the excess supply then the stock price tends to fall

According to Brigham and Houston (2010: 7) stock prices are "Stock prices determine shareholders' wealth. Maximizing shareholder wealth is translated into maximizing the company's share price. Stock prices at a given time will depend on cash flows that are expected to be received in the future by investors "on average" if investors buy shares ".

Based on the understanding of the experts above, it can be concluded that the stock price is the price formed according to the demand and supply in the market of buying and selling shares and this is usually the closing price.

\section{Fundamental Factors}

\subsection{Capital Adequacy Ratio (CAR)}

According to Bank Indonesia (Number 9/ 13 / PBI / 2007), CAR is the minimum capital provision for banks based on asset risk in the broadest sense, both assets listed in the balance sheet and administrative assets as reflected in liabilities that are still contingent and / or commitments provided by banks to third parties and market risks.

Based on the definition according to experts, it can be concluded that CAR is the bank's performance ratio to measure the capital adequacy of the bank to support assets that contain or produce risks, such as loans given to customers.

\subsection{Return on Asset (Roa)}

According to Hanafi and Halim (2007: 172), ROA is a ratio used to measure a company's ability to generate profits by using the total assets owned by the company after adjusting for the costs to fund the asset. Return On Assets (ROA) is the most important ratio among existing profitability ratios. Return on Assets (ROA) is obtained by comparing net income after tax to total assets. The higher ROA results of a company reflect that the low use of assets to generate profits.

\subsection{Net Interest Margin (NIM)}

Net Interest Margin (NIM) is a measure of the difference between interest income generated by banks or other financial institutions and the interest paid to their lenders (for example, deposits) relative to their assets (productive interest).

This is usually expressed as a percentage of what a financial institution obtains a loan in a period of time and other assets minus interest paid on loan funds divided by the average amount of fixed assets on income earned in that period (the earning average of assets) .

\subsection{Loan to Deposit Ratio (LDR)}

According Darmawi (2011: 61), LDR (Loan to Deposit Ratio) is one measure of liquid from supply concept in the form of loans to deposits ratio. According to Kasmir (2014: 225), LDR (Loan to Deposit Ratio) is the ratio used to measure the composition of the amount of credit given compared to the amount of public funds and the capital used.

From the definition of LDR according to experts above, it can be concluded the LDR is a ratio that measures the extent to which banks are able to repay withdrawals made by relying on loans provided as a source of liquidity. The higher of this ratio then it means that the low liquidity of the bank concerned. But on the contrary, if the lower the LDR ratio, the higher the liquidity of the bank concerned. This ratio is also an indicator of the vulnerability and ability of a bank. According to Kasmir (2014: 225), the safe limit of a bank's LDR is around 80\%. But the maximum LDR limit is $110 \%$. 


\subsection{Non Performing Loan (NPL)}

According to Ismail (2009: 224), non-performing loans is a condition in which the customer is not able to pay for part or all of its obligations to the bank as had been agreed.

Banks must be able to manage their credit well in giving credit to the community and in repaying loans in accordance with the applicable terms and conditions so as not to cause problem loans.

\section{Research Methods}

This type of research is causality research, which is research that aims to test hypotheses and find out the relationship and influence between two or more variables on other variables. This study aims to examine the effect of independent variables namely Capital Adequacy Ratio (CAR), Return On Assets (ROA), Net Internet Margin (NIM), Loan to Deposit Ratio (LDR), and Non Performing Loans (NPL) to the dependent variable namely price shares in Conventional commercial banks listed in LQ45.

This research is a type of applied research with analytical quantitative analysis. Quantitative research methods can be interpreted as research methods that are based on the philosophy of positivism, used to examine certain populations or samples.

Based on the theoretical basis that there are, banking Fluctuations in share price movements are influenced by factors of a company's financial ratios that the ratio can be formulated as follows :

\subsection{Capital Adequacy Ratio (CAR)}

The higher the value of CAR will make the better the performance of a bank. The amount of capital of a bank, will affect the level of public confidence in the performance of the bank. According to Hasibuan (2009: 58), the CAR ratio can be formulated as follows:

$\mathrm{CAR}=\frac{\text { Own Capital }(\text { Core Capital }+ \text { Complementary Capital })}{\text { ATMR }(\text { Asset Balance }+ \text { Administrative Balance })} \times 100 \%$

\subsection{Return on Asset (ROA)}

Return on Assets (ROA) is obtained by comparing net income after tax to total assets. The higher ROA results of a company reflect that the low use of assets to generate profits. According to Hasibuan (2009: 100), the ROA ratio can be formulated as follows:

$\mathrm{ROA}=\frac{\text { Net Income After Tax }}{\text { Total Aset }} \times 100 \%$

\subsection{Net Interest Margin (NIM)}

Net interest margins are similar in concept to spread net interest, but the spread of net interest is the nominal average difference between loans and loan interest rates, without compensation for the fact that productive assets and borrowed funds can be different and different tools in volume.

The ratio formula is:

$\mathrm{NIM}=\frac{\text { Interest Income }- \text { Interest Expense }}{\text { Average Interest Earning Asset }} \times 100 \%$

\subsection{Loan to Deposit Ratio (LDR)}

The LDR ratio is calculated by comparing credit with third party funds where the credit used is the total credit given to third parties, and does not include loans given to other parties. Whereas third party funds are demand deposits, savings, and deposits which are not included in the interbank. According to Sudirman (2013: 158), this ratio can be formulated as follows:

$\mathrm{LDR}=\frac{\text { Third Party Credit Amount) }}{\text { Total third party funds }} \times 100 \%$

\subsection{Non Performing Loan (NPL)}

The smaller of NPL value it means the smaller the credit risk borne by the bank. Banks in conducting credit must analyze the ability of the debtor to repay its obligations. After credit is granted, banks are required to monitor the use of credit and the ability and compliance of the debtor in fulfilling its obligations. The Bank conducts a review and binding of collateral to minimize credit risk. Banking practitioners agreed that the safe limit of a bank's NPL must not exceed $5 \%$. According to Ismail (2009: 228), this ratio can be formulated as follows:

$$
\mathrm{NPL}=\frac{\text { Problem Loans }}{\text { Total Credit }} \times 100 \%
$$

The population in this research is the Close Price data of conventional banks registered in LQ45 from 2013 to 2018. The sampling method used is purposive sampling method, where sampling is adjusted to the required sample requirements. The sample in this study is annual data (Capital Adequacy Ratio (CAR), Return on Assets (ROA), Net Interest Margin (NIM), Loan to Deposit Ratio (LDR) and Non-Performing Loans (NPL) in 2013 to 2018 where the Closing Price Bank listed in LQ45 fluctuated in the period. 
The type of data used in this study is quantitative data, based on the sources of the data used are secondary data with annual time series data types over a period of 6 years from 2013 to 2018. Secondary data sources are indirect sources provide data to data collectors, for example through other people or through documents (Jogiyanto, 2003).

The data used in this research is secondary data including stock price data (Closing Price) JCI banks listed in LQ45-year period from 2013 to 2018 were taken from Indonesian Stock Exchange (http:/ / idx.co.id/ data-pasar / report-statistics / summary-performance-company-lq45 / ). Data on the value of CAR, ROA, NIM, LDR and NPL in 2013-2017 taken from the Indonesia Stock Exchange website (LQ 45 Member Profile IDX index) (http://idx.co.id/data-pasar/laporanstatistik/ summary-performance company-lq45/ ) and also from the financial statements of BCA, BRI, Mandiri, BJB, BNI, and BTN banks in 2013-2018.

The data obtained from the results of subsequent research were analyzed by panel data regression analysis model using the program Eviews version 9 (which aims to determine the effect of Capital Adequacy Ratio (CAR), Return On Assets (ROA), Net Interest Margin (NIM), The Loan to Deposit Ratio (LDR) and Non Performing Loans (NPL) to the dependent variable is the Closing Price of Conventional Commercial Banks registered in LQ45. The equation of the research model using the panel data model in this study is as follows:

Yit $=\mathrm{a}+\beta_{1} \mathrm{CAR}_{\mathrm{it}}+\beta_{2} \mathrm{ROA}_{\mathrm{it}}+\beta_{3} \mathrm{NIM}_{\mathrm{it}}+\beta_{4} \mathrm{LDR}_{\mathrm{it}}+\beta_{5} \mathrm{NPL}_{\mathrm{it}}+\varepsilon_{\mathrm{it}}$

Description:

$\mathrm{Y}=$ Stock Price

$\mathrm{a}=$ Constant

$\beta=$ Regression line coefficient

CAR = Capital adequacy Ratio (CAR)

ROA $=$ Return On Assets (ROA)

$\mathrm{NIM}=$ Net Interest Margin (NIM),

LDR = Loan to Deposit Ratio (LDR)

NPL $=$ Non Performing Loan (NPL)

$\mathrm{e} \quad=$ Standard Error

In the research using panel data, known 3 (three) research model approaches, namely Common Effects (pooled least square-PLS), Fixed Model Effect (FEM) and Random Model Effect (REM). The purpose of model estimation is to determine which model is suitable for this research. The analysis used in this research is multiple regression analysis model by using hypothesis testing. The modern interpretation of regression is the study of the dependence of one dependent variable with one or more independent variables, in order to estimate and / or predict the average dependent variable based on the value of the known independent variable. The following below is a panel data testing framew ork :

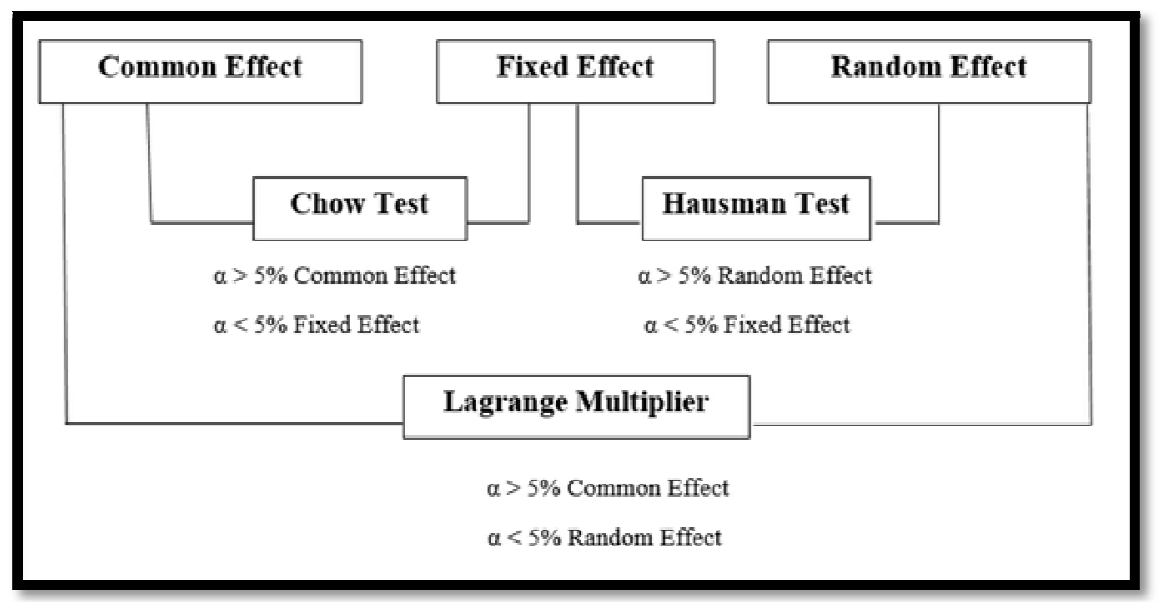

Figure 1

\section{Method of Selecting a Panel Data Model}

\subsection{Chow Test}

The Chow test or some books call it F statistics testing is a test to choose whether the model used is Pooled Least square or Fixed Effect.

In this test the hypothesis is carried out as follows:

$\mathrm{H}_{0}$ : Common Effect Model

$\mathrm{H}_{1}$ : Fixed Effect Model

In making a decision is to use probability probability numbers, namely:

If the probability of significance is $>0.05$, then $\mathrm{H}_{0}$ is accepted and $\mathrm{H}_{1}$ : is rejected.

If the probability of significance is $\varangle 0.05$, then $\mathrm{H}_{0}$ is rejected and $\mathrm{H}_{1}$ : is accepted. 


\subsection{Hausman Test}

Basically the Hausman test is used to see the consistency of estimation with OLS, so in panel data modeling, the Hausman test can be used to determine whether the model is Fixed Effect or Random Effect. The hypothesis used in this test is as follows:

$\mathrm{H}_{0}$ : Random Effect Model

$\mathrm{H}_{1}:$ : Fixed Effect Model

The basis for decision making is to use probability probability numbers, namely:

If the probability of significance is $>0.05$, then $\mathrm{H}_{0}$ is accepted and $\mathrm{H}_{1}$ is rejected.

If the probability of significance is $<0.05$, then $\mathrm{H}_{0}$ is rejected and $\mathrm{H}_{1}$ is accepted.

\subsection{Lagrange Multiplier Test}

According Widarjono (2007: 260), to determine whether the model Random Effect model is better than common models used Lagrange Multiplier Effect Model (LM).

This Lagrange Multiplier test is based on the chi-squares distribution with degrees of freedom (df) equal to the number of independent variables. The hypothesis used in this test is as follows:

$\mathrm{H}_{0}$ : Common Effect Model

$\mathrm{H}_{1}$ : Random Effect Model

The basis for decision making is to use probability probability numbers, namely:

If the probability of significance is $>0.05$, then $\mathrm{H}_{0}$ is accepted and $\mathrm{H}_{1}$ is rejected.

If the probability of significance is $\varangle 0.05$, then $\mathrm{H}_{0}$ is rejected and $\mathrm{H}_{1}$ is accepted.

To test the hypothesis to be analyzed (H1 - H6), hypothesis tested by partial test ( $\mathrm{T}$ test) and simultaneous test (F test) as follows :

\subsection{F Test (Simultaneous)}

The F statistical test basically shows whether all the independent variables or independent variables included in the model have a joint influence on the dependent variable or dependent variable (Ghozali, 2012: 98).

Hypothesis:

$\mathrm{H}_{0}=$ Independent variables together have no significant effect on the dependent variable.

$\mathrm{H}_{1}=$ Independent variables together have a significant effect on the dependent variable.

Basic decision making:

If the $\mathrm{p}$-value $>0.10$ then $\mathrm{H}_{0}$ is accepted

If the $\mathrm{p}$-value is $<0.10$ then $\mathrm{H}_{0}$ is rejected.

\subsection{Coefficient of Determination $\left(R^{2}\right)$}

The coefficient of determination essentially measures how far the model's ability to explain the variation of the dependent variable. The coefficient of determination is between 0 and one. A small $\mathrm{R}^{2}$ value means that the ability of independent variables to explain variations in the dependent variable is very limited. A value close to one means that the independent variables provide almost all the information needed to predict variations in the dependent variable (Ghozali, 2012: 97).

\subsection{T-statistic test}

The t statistical test basically shows how far the influence of one independent variable partially in explaining the variation of the dependent variable (Ghozali, 2012).

Hypothesis:

$\mathrm{H}_{0}=$ Independent variables together have no significant effect on the dependent variable.

$\mathrm{H}_{1}=$ Independent variables together have a significant effect on the dependent variable.

Basic decision making:

If the $\mathrm{p}$-value $>0.10$ then $\mathrm{H}_{0}$ is accepted

If the $\mathrm{p}$-value is $<0.10$ then $\mathrm{H}_{0}$ is rejected.

\section{Results and Discussion}

\subsection{Model Paired Test}

In determining the selection of the right model, it will be done Chow Test, Hausman test and Lagrange Multiplier Test. Based on the results of tests conducted, it can be concluded:

\begin{tabular}{|c|c|c|c|c|c|}
\hline & Method & & Testing & Results \\
\hline 1 & Chow Test & & PLS or Common Effect vs Fixed Effect & & Fixed Effect \\
\hline 2 & Hausman Test & & Fixed Effect vs Random Effect & & Fixed Effect \\
\hline
\end{tabular}

Table 1: Conclusions of Panel Data Regression Model Testing

The results of the panel data regression model test on the three panel data models, the purpose is to strengthen the conclusion of paired testing, which recommends the use of Fixed effect model to be analyzed further in this study. 


\begin{tabular}{|c|c|c|c|c|}
\hline \multicolumn{5}{|c|}{$\begin{array}{c}\text { Dependent Variable: Y (Stock Price) } \\
\text { Method: Panel Least Squares } \\
\text { Date: 04/ 15/ } 19 \text { Time: 19:31 } \\
\text { Sample: } 20132018 \\
\text { Periods included: } 6 \\
\text { Cross-sections included: } 6 \\
\text { Total panel (balanced) observations: } 36\end{array}$} \\
\hline Variable & Coefficient & Std. Error & t-Statistic & Prob. \\
\hline $\mathrm{C}$ & 16698.51 & 22444.92 & 0.743977 & 0.4638 \\
\hline $\mathrm{X} 1$ & 608.8587 & 290.2227 & 2.097902 & 0.0462 \\
\hline $\mathrm{X} 2$ & -1267.178 & 1472.134 & -0.860777 & 0.3975 \\
\hline X3 & 720.6818 & 1568.585 & 0.459447 & 0.6499 \\
\hline $\mathrm{X} 4$ & -256.8756 & 211.1542 & -1.216531 & 0.2351 \\
\hline \multirow{2}{*}{\multicolumn{5}{|c|}{\begin{tabular}{c|c}
573.2616 & 1020.893 \\
Effects Specification
\end{tabular}}} \\
\hline & & & & \\
\hline \multicolumn{5}{|c|}{ Cross-section fixed (dummy variables) } \\
\hline R-squared & 0.811736 & \multicolumn{2}{|c|}{ Mean dependent var } & 7335.000 \\
\hline Adjusted R-squared & 0.736431 & \multirow{2}{*}{\multicolumn{2}{|c|}{$\begin{array}{l}\text { S.D. dependent var } \\
\text { Akaike info criterion }\end{array}$}} & 5929.502 \\
\hline S.E. of regression & 3044.145 & & & 19.12630 \\
\hline Sum squared resid & $2.32 \mathrm{E}+08$ & \multicolumn{2}{|c|}{ Schwarz criterion } & 19.61015 \\
\hline Log likelihood & -333.2733 & \multirow{2}{*}{\multicolumn{2}{|c|}{$\begin{array}{l}\text { Hannan-Quinn criter. } \\
\text { Durbin-Watson stat }\end{array}$}} & 19.29517 \\
\hline F-statistic & 10.77925 & & & 1.077192 \\
\hline Prob(F-statistic) & 0.000001 & \multicolumn{2}{|c|}{ Durbin-Watson stat } & \\
\hline
\end{tabular}

Table 2: Random Effects Test Results

Source: Data is processed with E-Views 9.0

By using the Eviews program, where the panel fixed effect model data regression equation is obtained as follows:

Yit $=\mathrm{a}+\beta_{1} \mathrm{CAR}_{\mathrm{it}}+\beta_{2} \mathrm{ROA}_{\mathrm{it}}+\beta_{3} \mathrm{NIMR}_{\mathrm{it}}+\beta_{4} \mathrm{LDR}_{\mathrm{it}}+\beta_{5} \mathrm{NPL}_{\mathrm{it}}+\varepsilon_{\mathrm{it}}$

So that the panel data regression equation model can be formulated as follows:

Yit $=16.698,51+608,85 \mathrm{CAR}-1.267,17 \mathrm{ROA}+720,68 \mathrm{NIM}-256,87 \mathrm{LDR}+573,26 \mathrm{NPL}+\varepsilon_{\text {it }}$

This equation explains:

- Constant $=16,698.51$, Values in positive constants indicate that all independent variables (CAR, ROA, NIM, LDR, and NPL) are considered not constant or increased by 16,698.51.

- $\operatorname{CAR}\left(\mathrm{X}_{1}\right)=608,85$, is a variable regression coefficient value of the Capital Adequacy Ratio on banking stock prices. If there is an increase in the variable CAR of one unit, then the stock price variable (Y) increased or otherwise amounted to 608.85 assuming $\mathrm{X}_{2}, \mathrm{X}_{3}, \mathrm{X}_{4}$, dan $\mathrm{X}_{5}$ constant.

- $\operatorname{ROA}\left(X_{2}\right)=-1267,17$, Is a Return on Asset variable regression coefficient value on banking stock prices. If there is an increase in ROA by one unit, then the stock price variable (Y) increased or otherwise amounted to -1267.17 assuming the variables $\mathrm{X}_{1}, \mathrm{X}_{3}, \mathrm{X}_{4}$, dan $\mathrm{X}_{5}$ constant.

- $\operatorname{NIM}\left(X_{3}\right)=720,68$, is the variable value of the Net Interest Margin coefficient value on banking stock prices. If there is an increase in NIM variable by one unit, then the stock price variable (Y) increased or otherwise amounted to 720.68 , assuming the variables $\mathrm{X}_{1}, \mathrm{X}_{2}, \mathrm{X}_{4}$, dan $\mathrm{X}_{5}$ constant.

- $\operatorname{LDR}\left(\mathrm{X}_{4}\right)=-256,87$, is a variable regression coefficient value of Loan Deposit Ratio to banking stock prices. If there is an increase in LDR variable by one unit, then the stock price variable (Y) increased or otherwise of -256.87 assuming the variables $X_{1}, X_{2}, X_{3}$, dan $X_{5}$ constant.

- $\operatorname{NPL}\left(X_{5}\right)=573,26$, It is the Non-Performing Loan variable regression coefficient value against banking stock prices. If there is an increase in the variable NPLs by one unit, then the stock price variable $(\mathrm{Y})$ increased or otherwise amounted to 573.26, assuming the variables $\mathrm{X}_{1}, \mathrm{X}_{2}, \mathrm{X}_{3}$, dan $\mathrm{X}_{4}$ constant.

\begin{tabular}{|c|c|}
\hline F-statistic & $\mathbf{1 0 . 7 7 9 2 5}$ \\
\hline Prob(F-statistic) & 0.000001 \\
\hline
\end{tabular}

Table 3: Output of F Test on Fixed Effect Model

Source: Eviews 9.0 data processing

In the table above the value of $\mathrm{p}$-value $=0.000001<0.10$, so that $\mathrm{H}_{0}$ is rejected which means that the independent variables together have a significant effect on the dependent variable.

\begin{tabular}{|c|c|}
\hline F-statistic & $\mathbf{1 0 . 7 7 9 2 5}$ \\
\hline Prob(F-statistic) & 0.000001 \\
\hline \multicolumn{2}{|c|}{ Table 4: Test Results $\left(R^{2}\right)$ In Fixed Effect Model } \\
Source: E views 9.0 Data Processing
\end{tabular}


The R-square value $\left(\mathrm{R}^{2}\right)=0.7364$ in table above shows that $73.64 \%$ of the variance in banking stock prices can be explained by changes in the variables CAR, ROA, NIM, LDR, and NPL. While the remaining $26.36 \%$ is explained by other factors outside the model.

\begin{tabular}{|c|c|c|c|c|}
\hline Variable & Coefficient & Std. Error & t-Statistic & Prob. \\
\hline C & 16698.51 & 22444.92 & 0.743977 & 0.4638 \\
\hline CAR & 608.8587 & 290.2227 & 2.097902 & 0.0462 \\
\hline ROA & -1267.178 & 1472.134 & -0.860777 & 0.3975 \\
\hline NIM & 720.6818 & 1568.585 & 0.459447 & 0.6499 \\
\hline LDR & -256.8756 & 211.1542 & -1.216531 & 0.2351 \\
\hline NPL & 573.2616 & 1020.893 & 0.561529 & 0.5794 \\
\hline \multicolumn{3}{|c|}{$\begin{array}{c}\text { Effects Specification } \\
\text { source: Eviews 9.0 }\end{array}$} & \\
\hline
\end{tabular}

Table 5: T Test Resultsin Fixed Effect Model

The table above is the result of partial test output ( $t$ ) in Fixed Effect Model. It can be seen that the CAR variable has a significant positive effect on stock prices because the value of $p$ value $=0.04<0.1$ while the ROA variable has no significant effect and negatively correlates to stock prices because $\mathrm{p}$ value $=0.39>0.1$. The value of the NIM variable also has no significant effect and is positively correlated with the stock price indicated by the $p$ value $=0.64>0.1$. Likewise with LDR variables partially no significant effect but negatively correlated with $p$ value $=0.23>0.1$ and NPL also does not significantly influence and positively correlate with stock prices with $p$ value $=0.57>0.1$

\section{Results Interpretation of Research}

Based on the analysis of research results that have been described first, then in this sub-chapter a discussion is conducted to prove the hypothesis. The discussion was conducted by describing the strong influence between the independent variables consisting of CAR, ROA, NIM, LDR and NPL on the banking stock prices listed in LQ45.

\subsection{The Effect of Capital Adequacy Ratio (CAR) on Stock Prices}

Capital Adequacy Ratio (CAR) is a variable that has a positive effect on banking stock prices. The treatment of the direction test found a coefficient of 608.85 . From these numbers, it can be interpreted that the relationship between the CAR variable and the banking stock price is a direct and positive relationship.

This means that the higher the value of the CAR ratio, the higher the stock price of the bank because the higher the CAR the better the performance of a bank. The amount of capital of a bank, will affect the level of public confidence in the performance of the bank. Likewise, on the contrary, the smaller the value of the CAR ratio, the smaller the stock price of the bank. Banking companies that have a high CAR ratio value will find it easier to get investors to invest compared to banks that have a smaller CAR ratio because banking stock prices are higher.

This result is in line with previous research from Setyaningsih Sri Utami (2005), Dahrul Aman Harahap, Ade Isyana Hairunnisah, Hariaudy Hasbi (2010) Boni Agave, Martha Efrani, Sri Rosmalena (2018).

\subsection{The Effect of Return on Assets (ROA) on Stock Prices}

With a probability level of $90 \%(\alpha=10 \%)$, then the value is $>0.10$ so that this variable is in the acceptance area of $\mathrm{H} 0$, which means that the variable Return on Assets (ROA) is a variable that does not affect banking stock prices. The treatment for the direction test found a coefficient of 1267,178. From these figures it can be interpreted that the relationship that occurs between the ROA variable and banking stock price is the opposite (negative) relationship and not significant.

This result is in line with previous research from Daniarto Raharjo, Dul Muid, Setyaningsih Sri Utami (2005), Dahrul Aman Harahap, Ade Isyana Hairunnisah, Gerald Edsel et al (2017), Devinta Fulvia Alvianji and Fransiska Soejono (2014), Hariaudy Hasbi (2010) , and Joseph MJ Renwarin (2017). This shows that banks that have a high ROA do not necessarily have high stock prices because banks that generate profits from larger assets are used (lower ROA) will result in higher banking stock prices so investors are more interested.

\subsection{The Effect of Net Interest Margin (NIM) on Stock Prices}

With a probability level of $90 \%(\alpha=10 \%)$, the value is $>0.10$ so that this variable is in the acceptance area of $\mathrm{H} 0$, which means that the variable Net Interest Margin (NIM) is a variable that does not affect the banking stock price. The treatment of the direction test found a coefficient of 720.68. From these figures, it can be interpreted that the relationship between the NIM variable and the banking stock price is a unidirectional but not significant relationship.

This result is in line with previous research from Erna Indah Sari et al (2011), Y. Sunyoto and Sam'ani (2014), Yuni Yolanda Sari et al (2018), and Dede Junarko (2015).

This condition indicates that Net Interest Margin (NIM), which is a high net interest margin, will result in a high but not significant banking stock price. The greater the Net Interest Margin (NIM), the better the bank. Net Interest Margin (NIM) shows the level of profitability of a bank. Banks with a greater Net Interest Margin (NIM) means more efficient use of their assets to generate profits, but this does not affect the Stock Price. The higher Net Interest Margin (NIM) indicates 
that investors do not consider banking efficiency as important to their assets. Investors tend to pay more attention to their investment security and dividends obtained.

\subsection{The Effect of Loan Deposit Ratio (LDR) on Stock Prices}

With a probability level of $90 \%(\alpha=10 \%)$, the value is $>0.10$ so that this variable is in the acceptance area of $\mathrm{H} 0$, which means that the variable Loan Deposit Ratio (LDR) is a variable that does not have a significant effect on banking stock prices. The treatment of the direction test found a coefficient of -256.87. From these figures, it can be interpreted that the relationship that occurs between the LDR variable and banking stock price is the opposite (negative) and not significant relationship.

These results are in line with previous research from Yuneita Anisma (2012), Dahrul Aman Harahap et al (2017), Catriwati (2017), Anggela A. Adam (2018), Masril (2018), Hariaudy Hasbi (2010), Joseph MJ Renwarin ( 2017).

From the results of the study it can be explained that, in accordance with Bank Indonesia regulations, the bank's Loan Deposit Ratio (LDR) limit should not exceed $110 \%$, so if there are banks that have a high Loan Deposit Ratio (LDR), the bank has the potential too high. Due to the high Loan Deposit Ratio (LDR), there is a gap between the amount of credit and the amount of deposits, which has an impact on the lower bank liquidity, this has an impact on the condition of the bank and subsequently will affect the level of investor confidence which causes the stock price to decline. This is in accordance with the theory of Suad (2001), where changes in the composition of debt have an impact on stock prices. So it can be concluded that the higher the Loan Deposit Ratio (LDR), the Share Price will decrease as well as vice versa, the lower the Loan Deposit Ratio, the higher the stock price will be.

\subsection{The Effect of Non Performing Loans (NPL) on Stock Prices}

With a $90 \%$ probability level $(\alpha=10 \%)$, the value is $>0.10$ so that this variable is in the $\mathrm{H} 0$ acceptance area, which means that the Non Performing Loan (NPL) variable is a variable that does not significantly influence banking stock prices. The treatment of the direction test found a coefficient of 573.26. From these figures it can be interpreted that the relationship that occurs between the NPL variable and banking stock price is a unidirectional but not significant relationship.

These results are in line with previous studies from the research of Sigit Dwi Wismaryanto (2013), Sandro Heston Sambul et al (2016).

The Hypothesis Test results state that the Non Performing Loan (NPL) variable does not have a significant effect on stock prices. The more non-performing loans, the opportunity for banks to get profits will be less so that with a high NPL in banks investors will not be interested in buying shares because the profits will be small but in banks included in LQ45 with a very good CAR ratio (mean $=16.33-20.02$ ) has good capital adequacy which makes banking stock prices high and becomes the biggest attraction for investors to buy banking shares. So that even though the NPL value is high, investors still feel safe in investing so that the NPL is not a benchmark for investors in making decisions.

\section{Conclusion}

The results of testing the data using the Eviews 9.0 tool obtained the FEM model (Fixed Effect Model), after the F test was carried out the independent variables were found to have a significant effect on the dependent variable. The Rsquare value $\left(R^{\wedge} 2\right)=0.7364$ in the table above shows that $73.64 \%$ of the variance in banking stock prices can be explained by changes in the variables CAR, ROA, NIM, LDR, and NPL. While the remaining $26.36 \%$ is explained by other factors outside the model.

Based on the results of the analysis and discussion, the following are summarized as follows:

- Variable Capital Adequacy Ratio (CAR) partially has a significant positive effect on the banking stock prices listed in LQ45.

- Variable Return On Assets (ROA) partially does not have a significant effect on banking stock prices listed in LQ45.

- The variable Net Interest Margin (NIM) partially does not have a significant effect on the banking stock price listed in LQ45.

- Variable Loan Deposit Ratio (LDR) partially does not have a significant effect on banking stock prices listed in LQ45.

- The Non Performing Loan (NPL) variable partially does not have a significant effect on the banking stock price registered in LQ45.

\section{Suggestion}

Based on the results of the discussion and conclusions regarding the variables which include CAR, ROA, NIM, LDR, and NPL on banking stock prices registered in LQ45, the author tries to convey some suggestions for consideration including the following:

- For a banking company whose share price is registered in LQ45 in maximizing banking stock prices in order to compete in the Indonesia Stock Exchange, it is necessary to maintain the bank's capital adequacy ratio to support assets by considering the Capital Adequacy Ratio (CAR) ratio. affect the banking stock price in LQ45.

- For academics, this study can be useful for those who want to know how much influence CAR, ROA, NIM, LDR, and NPL have on banking stock prices registered in LQ45 in the period from 2013-2018. Especially for the next researcher, with this research, the next researcher is expected to be able to carry out further research related to the factors that influence banking stock prices. 
- Even though Return on Assets (ROA), Net Interest Margin (NIM), Loan Deposit Ratio (LDR), and Non Performing Loans (NPL) in this study partially have no significant effect on Stock Prices, we recommend that ROA and NIM be while the LDR and NPL must be minimized because these variables are an evaluation of how the bank performs in generating profits. With the increase in Net Interest Margin (NIM) and Return on Assets (ROA), and maintain the value of the LDR and NPL ratio, the profits generated by banks will increase, this will affect the welfare of banks, shareholders and all employees.

\section{References}

i. Anisma, Yuneita. (2012). "Faktor-Faktor yang Mempengaruhi Harga Saham Perusahaan Perbankan yang Listing di Bursa Efek Indonesia (BEI)".Jurnal Sosial Ekonomi Pembangunan, Tahun II , No. 5, hal 144-165.

ii. Agave, Boni; Martha Efrani, dan Sri Rosmalena. (2018). "Effect Of Financial Performance Of Banking Companies To Stock Return (Empirical Studies On Banking Companies Listed In Indonesia Stock Exchange In The Year of 2011 2015 ) . International Journal of Economics, Business and Management Research Vol. 2, No. 03, hal 377-394.

iii. Alwi, Iskandar Z, (2008). Pasar Modal Teori dan Aplikasi, Yayasan Pancur Siwah, Jakarta.

iv. A. Adam, Angela. (2018). "Analysis the Influence Of Ratio Camel to Share Price On Company Banking Which Enlist In BEI Year 2010-2013". E-Jurnal Sariputra, Februari 2018 Vol. 5 (1) hal 67-73.

v. Catriwati. (2017).”Pengaruh Capital Adequacy Ratio (CAR), Return On Aset (ROA), Loan Deposit Ratio (LDR), Net Interest Margin (NIM), Non Performing Loan (NPL), dan Asset Growth Terhadap Harga Saham Perbankan yang Terdaftar di Bursa Efek Indonesia". Jurnal Intra-Tech Volume 1, No.2 , hal 76-91.

vi. vi.DDaniarto, Raharjo, dan Dul Muid . (2013). " Analisis Pengaruh Faktor-Faktor Fundamental Rasio Keuangan Terhadap Perubahan Harga Saham". Diponogoro Journal Of Accounting, Volume 2, Nomor 2, Tahun 2013, Halaman 1-11.

vii. Edsel, Gerald; Ventje Ilat, dan Sonny Pangerapan. (2017). "The Influences Of Return On Asset (ROA), Return On Equity (ROE), Net Profit Margin (NPM) , and Earning Per Share (EPS) Against The Stock Prices Of The Companies Listed On LQ45 Index In Indonesian Stock Exchange On the Period Of 2013-2015”. Jurnal EMBA Vol.5 No.1 Maret 2017, Hal. 105 - 114.

viii. Fulvia, Devinta, dan Fransiska Soejono (2014). “Kinerja Bank dan Harga Saham”. Jurnal Keuangan dan Bisnis, Vol. 12, No. 2, hal 142-162.

ix. ix.Ginting, Suriany. (2013). "Analisis Faktor0Faktor yang Mempengaruhi Harga Saham pada Perusahaan di Bursa Efek Indonesi". Jurnal Wira Ekonomi Mikroskil Volume 3, Nomor 02, hal 142-163.

x. Harahap, Dahrul Aman dan Ade Isyana Hairunnisah. (2017). "The Effect of NPL, LDR, GCG, NIM, ROA, ROE, CAR, BOPO Towards The Stock Price In Banking Companies Listed In Indonesian Stock Exchange Of The Year 20102014". Jurnal Dimensi, VOL. 6, NO. 1: 22-40.

xi. Hartanto dan Diansyah . (2018). "Pengaruh Kinerja Keuangan Terhadap Harga Saham Bank Umum Swasta Nasional yang Terdaftar di Bursa Efek Indoneisa”. Journal Of Business Studies, Vol.3, No.1, hal 45-57.

xii. Hasby, Hariandy. (2010). "The Influence of Banking on Financial Performance to Stock Price in Indonesia". 3.d International Conference on Quantitative Methods Used in Economics and Business (ICQMEB 2010) ,Universitas Malahayati ,Bandarlampung.

xiii. xiii.Heston Sambul, Sandro.(2016). "Pengaruh Kinerja Keuangan Perbankan Terhadap Harga Saham yang ditawarkan di Bursa Efek Indonesia (Studi kasus 10 Band dengan Aset Terbesar)”. Jurnal Berkala Ilmiah Efisiensi, Volume 16, No. 02, hal 407-417.

xiv. Husnan, Suad, (2005). Dasar-Dasar Teori Portofolio dan Analisis Sekuritas, Edisi Ketiga, UPP AMP YKPN, Yogyakarta.

xv. Irawan, Candra. (2017)." CAR , NPL yang Mempengaruhi Terhadap Harga Saham Dengan Laba Bersih Sebagai Variabel Moderating Pada Perbankan di BEI 2009-2015”.Jurnal Wira Ekonomi Mikroskil Volume 7, Nomor 01, hal 71-78.

xvi. Masril. (2018) . "Pengaruh CAR dan LDR terhadap Harga Saham pada Perbankan di Bursa Efek Indonesia”. Jurnal samudera Ekonomi dan Bisnis, Vol 9, No 2 hal 150-159.

xvii. M J Renwarin, Joseph. (2017). "The Influence of Financial Performance and Financial Distress On Stock Price". International Journal of Technical Research and Applications e-ISSN: 2320-8163, www.ijtra.com,Volume 5, Issue 1 (Jan-Feb 2017), PP.47-55.

xviii. Putri, Rescyana. (2012). "Pengaruh Dividend Per Share, Return On Equity, dan Net Interest Margin Terhadap Harga Saham Perusahaan Yang Tercatat di Bursa Efek Indonesia Periode 2006-2010”. Jurnal Nominal / Volume I Nomor I hal 104-123.

xix. xvix. Rapina.(2011). "Analisis Pengaruh Rasio CAMEL Terhadap Harga Saham Bank Yang Listing di Bursa Efek Indonesia Periode 2006-2009". Jurnal Ekonomi dan Bisnis ,Vol 2 ,no 1, hal 39-59.

xx. Sutrisno, (2005). Manajemen Keuangan, Teori, Konsep, dan Aplikasi, Ekonisia, Yogyakarta.

xxi. http:/ / hehepangibulan.blogspot.com/ 2013/ 05/ 6tingkat-kesehatan-bank camels.html

xxii. Sarwono, Jonathan dan Hendra N.S. (2014). E Views : Cara Operasi dan Prosedur Analisis. Penerbit Andi ,Yogyakarta.

xxiii. xxiii.https:/ / www.cnnindonesia.com/ ekonomi/ 20181231060503-92-357411/ saham-bank berkilau-jika-2019fed-tahan-kenaikan-bunga 
xxiv. Setiawan, Alwin. Dan Launw Tjun Tjun. (2010). "Pengaruh Earnings Per Share (EPS), Loan To Deposit Ratio (LDR), dan Arus Kas Operasi terhadap Harga Saham Emiten Sektor Perbankan di Bursa Efek Indonesia”. Jurnal Akuntansi Vol.2 No.2 November 2010: 162-180.

xxv. Sri Utami, Setyaningsih. (2005). "Pengaruh Rasio keuangan Terhadap Harga Saham (Studi pada Perusahaan Perbankan di Bursa Efek Jakarta)". Jurnal Ekonomi dan Kewirausahaan Vol. 5, No. 2, Oktober 2005 : 110 - 122.

xxvi. Takarini, Nurjanti dan Ukki Hayudanto Putra. (2010). "Dampak Tingkat Kesehatan Bank Terhadap Perubahan Harga Saham Pada Perusahaan Perbankan yang Go Public di Bursa Efek Indonesia (BEI)”. Jurnal Riset Ekonomi \& Bisnis, Vol. 10, No. 2, hal 83-92.

xxvii. Y. Sunyoto, dan Sam'ani. (2014). "Pengaruh Capital Adequacy Ratio, Net Interest Margin dan Return on Asset Terhadap Harga Saham pada Perbankan di BEI Periode 2009 - 2012". Jurnal Ekonomi Manajemen dan Akuntansi No. 36 / Th. XXI / hal 1-19.

xxviii. Yolanda, Sari; Budi Yanti dan Liza Zulbahri. (2018). "Pengaruh Kinerja Keuangan terhadap Harga Saham (Studi pada Sub Sektor Perbankan BUMN di Bursa Efek Indonesia Tahun 2012-2016)". Jurnal Manajemen dan Kewirausahaan, Volume 9, Nomor 1, hal 27-46. 